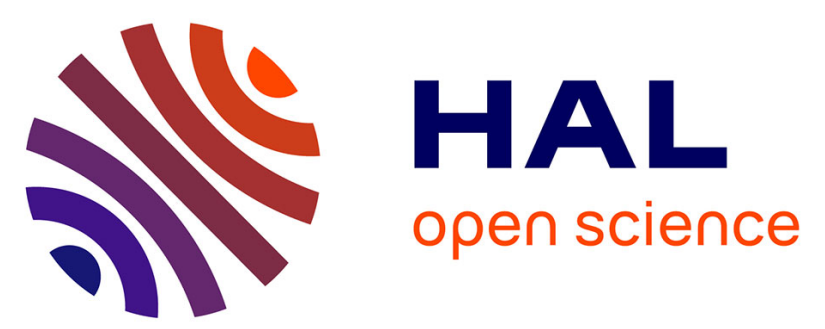

\title{
The Moroccan Moment and Communities of Itinerants: Mobility and Belonging in the Transnational Trajectories of Sub-Saharan Migrants
}

\author{
Johara Berriane
}

\section{- To cite this version: \\ Johara Berriane. The Moroccan Moment and Communities of Itinerants: Mobility and Belonging in the Transnational Trajectories of Sub-Saharan Migrants. Forging African Communities Mobility, Integration and Belonging, Palgrave Macmillan UK, pp 79-101, 2018, Global Diversities, 10.1057/978- 1-137-58194-5_4. hal-02390510}

\section{HAL Id: hal-02390510 https://hal.science/hal-02390510}

Submitted on 3 Jul 2020

HAL is a multi-disciplinary open access archive for the deposit and dissemination of scientific research documents, whether they are published or not. The documents may come from teaching and research institutions in France or abroad, or from public or private research centers.
L'archive ouverte pluridisciplinaire HAL, est destinée au dépôt et à la diffusion de documents scientifiques de niveau recherche, publiés ou non, émanant des établissements d'enseignement et de recherche français ou étrangers, des laboratoires publics ou privés. 
This is an original manuscript/preprint of a book chapter published in 2018 by Palgrave Macmillan in the volume Forging African Communities. Mobility, Integration and Belonging edited by Oliver Bakewell and Loren B. Landau, pp. 79-101, available online https://doi.org/10.1057/978-1-137-58194-5

\section{The Moroccan moment and communities of itinerants: mobility and belonging in the transnational trajectories of sub-Saharan migrants}

Johara Berriane

Introduction

Drawing upon the experiences of sub-Saharan migrants in Fès, Morocco, this chapter analyses the effects of strangers' presence on the places they pass through or where they temporarily settle. It explores the interactions and socialities that emerge within these 'semipermanent' settlements and analyses the effects of mobile groups' temporal installations in establishing and institutionalising social relations. This chapter further shows how migrants who are officially unwelcome in Morocco and largely uninterested in staying, claim both the right to be mobile and rights to the cities through which they pass. This is seen most acutely in their everyday practices and social relationships as they participate in urban life (Gilbert and Dikeç 2008 ).

Given its history and position on current migration routes, Fès represents a prime place to analyse the spatial effects of sub-Saharan migrants' temporal installation. These people settle in an urban space that has been historically shaped by the presence of others from subSaharan Africa from different social groups. With the exception of slaves, they too have contributed to shaping the local urban space by their temporal rather than permanent presence and socio-economic participation. After a short introduction of the theoretical reflections regarding the social impact of mobile individuals on place and communities, this paper describes the settlement patterns of the sub-Saharan migrants encountered in Fès and analyses the forms of host-guest relationships taking place in the city. More specifically, it explores how spatial and social distancing is coupled with the political integration of migrants.

Whereas mobility is generally conceived as being 'fundamental to any understanding of African social life' (De Brujn and Van Dijk 2001, pp.2-3) and contributes in the production and maintaining of social networks and institutions (De Brujn, van Dijk and van Dijk 2001; Boesen and Marfaing 2007), we often conceptualise the perilous journey of sub-Saharan 
migrants heading to Europe and crossing North Africa as a rupture and emancipation from their society of origin (Bredeloup 2013a). Since the end of the 1990s, Morocco has become a transit space for a growing number of migrants from West and Central Africa heading toward Europe. With the increasing tightening of European border controls, many of these have become trapped in Morocco and have subsequently had to rethink their migration projects. Starting in the 2000s, Morocco's policy towards undocumented migrants has also become more repressive. This has made the stay in Morocco increasingly uncertain and unstable. Whereas an increasing number of professional sub-Saharan migrants have been able to integrate in Morocco (Kettani and Peraldi 2011) and receive residency status, the existence of sub-Saharan squatter settlements along the Spanish-Moroccan border speaks to the persistence of ephemeral installations. Mobility was and is still a main feature of the subSaharan migration encountered in Morocco and Morocco represents still today a transit space for migrants.

Although it is only in the last twenty years that Morocco has become a 'transit' space for subSaharan migrants, the country has long been influenced by its connections with sub-Saharan Africa (Marfaing and Wippel 2004). The city of Fès in particular has been shaped by the circulation and temporal settlement of sub-Saharan individuals for centuries. The religious role of Fès has particularly contributed to the temporal installations of sub-Saharan individuals such as the Tidjani pilgrims who, since the late $19^{\text {th }}$ century have travelled to Fès to visit the tomb of the founder of their Sufi order (Berriane 2016). With its theological university of the Qarawiyine founded in the ninth century, Fès has long been an important intellectual centre for Africans. Since the 1980s, the number of sub-Saharan students in Fès has further increased with a variety of African countries now registered in the city's public and private universities (Berriane 2012).

Besides the ephemeral presence of West African pilgrims and students, the presence of subSaharan individuals in Fès was also historically linked to Morocco's slave history. Despite the closing of Morocca's last slave markets under French colonial rule in the 1920s, it was common until the 1950s to find black slaves working as servants for rich families (AouadBadoual 2004). Today, Fès remains an important place of transit and temporal settlement for sub-Saharan African migrants.

Based on 34 qualitative interviews conducted with sub-Saharan migrants living in the Moroccan city of Fès in summer 2010, ${ }^{1}$ this paper focuses on a social category of migrants for

\footnotetext{
${ }^{1}$ This research was part of the research project 'New Mobilities around Morocco viewed through the case of Fès' carried out in the frame of the programme 'African Perspectives on Human Mobility' (Université Mohamed V Rabat and International Migration Institute). This study found out that - as in most other Moroccan cities - sub-Saharan migrants living in Fès are mainly from West Africa (84.64 per cent), while only a minority is from Central Africa (10.51 per cent). The sub-Saharan migrants who took part in the survey were primarily men (77.4 per cent), aged between 20 and 35 years old (91 per cent), with most of them having received a school education (92.7 per cent), while 14 per cent had graduated from university before going abroad. The investigation comprised of a survey among 400
} 
whom Morocco was mainly conceived as being a site of transit: temporary and a space of 'inbetweeness' (Pian 2009b). It analyses the social effects of the ephemeral yet important presence of would-be transit and attempts to grasp the socialities that emerge during their stay in Morocco. In this way we can see 'moments' in much longer migration trajectories as socially generative.

The social impacts of mobile individuals: interactions with guests and the formation of communities of itinerants

Many researchers have argued that itinerant groups have a limited social impact on the societies where they stay. In reflecting on the cultural effects of migration on human history, Park, for instance, distinguishes clearly between migration - that 'involves [...] changes of residence and the breaking of home ties' and has a decisive impact on cultural and social changes - and the constant wanderings of Gypsies or nomads that brings few important changes in cultural life' and should 'be regarded rather as a geographical fact than a social phenomenon' (Park 1928, pp.886-887). This early $20^{\text {th }}$ century interpretation of the anti-social effect of unsettled groups may be moderated today, but it resonates with the conception of mobility as 'a special and temporary phenomenon' in contrast with the 'natural' state of people which is couched in terms of stability and coherence (De Bruijn, van Dijk and van Dijk 2001, p.64). It further implies that constant mobility is 'the direct aggressor' to places: that it prevents or erodes social formations and people's natural sense of space (Adey 2009, p.54). Simmel's discussion of the stranger, as a 'wanderer who comes today and stays tomorrow', suggests that the foreigner who settles permanently becomes socially relevant for the host society (Simmel 2009, p.601). This implies that the extent of the impact of guests on the host society depends on the duration of their stay. Other authors, while drawing on Simmel's concept of strangerhood, are rather more nuanced about temporality's impact on the stranger-host relationship. For Levine, the critical variable is not the length of time spent in the host community, but the type of relationship which the stranger and the host aspire to establish with each other (Levine 1979, pp.30-32). Strangers may merely wish to visit, content to remain an outsider throughout their stay; or they may hope to establish longer-term residence in a site without becoming assimilated into it. Alternatively, they may aspire to gain membership as fully integrated members of the host society. Furthermore, host society responses play a major role in determining the nature of the stranger-host relationship. These responses may be influenced by factors such as the physical appearance of the outsider and the manner in which they arrive; whether as individuals or an undifferentiated and potentially threatening group (Ibid.). Prior contacts between strangers and hosts along with the hosts' experiences with other strangers - that is, the intercultural experiences of the hosts and guests - further shape current interactions (Gudykunst 1983, pp.401-413). Regardless of past experiences, intergroup interactions are often negative when they occur in

sub-Saharan migrants and 34 biographical interviews with migrants who had been living in Fès in the summer of 2010. 
contexts of perceived or actual competition for jobs or other resources (Abel and Raul 2013, p.57).

We might assume that the sense of being out of place and limited contact with hosts are prominent characteristics of populations whose aim is not to integrate but to transit. Unlike nomadic groups or seasonal migrants, sub-Saharan migrants heading towards Europe hope to cross West and North Africa as quickly as possible to reach their destination. Furthermore, their travelling is not conceived as a way of life but rather represents an instrumental step or phase (Bredeloup 2013b, p.178) to be passed through to achieve their aim. Nonetheless, this form of journey does not take place without forging of social ties set in the particular times and spaces where they stay. For many these become 'circumstantial solidarities' employed to progress along their journey (Bredeloup 2013a, pp.517-532). In contrast to the 'grid-like understandings of strong and weak ties', the 'transient social ties' built by sub-Saharan migrants during their North African journey towards Europe function as 'bridges' that help migrants in their migration process but are malleable in the dynamic context of migration trajectories (Schapendonk 2012, p.36). These social ties shape a sense of belonging among migrants who form 'communities of itinerancy' in which gifts and debts are exchanged, while a collective consciousness is fostered among people who did not previously know each other (Escoffier 2008). Informed by logics of itinerancy, these associational forms are ephemeral; moments of social engagement may be immediately followed by the withdrawal of the individual migrant in order to pursue his or her route and projects alone (Alioua 2011, p.36).

The impact of itinerant migrants on the social world of the Sahara Desert has been carefully analysed, pointing out the key role that itinerant groups can play on 'transit spaces' (Bredeloup 2012, p.461). In contrast, the social interactions between transient migrants and the 'settled' communities they encounter during their sojourn in North Africa have so far been little studied. ${ }^{2}$ This rest of this chapter examines these interactions for the case of subSaharan migrants in Morocco, asking to what extent sub-Saharan itinerant migrants play a similar role to Simmel's strangers and what impact they have on Moroccan society.

The unstable settlement of sub-Saharan migrants in Morocco

Frequent movements are a major part of the lived experience of many sub-Saharan migrants. As during their overland journey through West and North Africa, migrants' life in Morocco is characterised by residential instability caused by Morocco's repressive migration policy towards undocumented migrants combined with migrants' own aspirations to move. Within this environment of instability, migrants' lives coalesce in various social formations around their shared experience of seeking cracks in Moroccan policies and striving to reach Europe.

\footnotetext{
2 Alioua mentions that the migrants build relations with Moroccans encountered in Rabat who also aspire to emigrate, but he does not give further details about the type and length of these relationships (Alioua 2011).
} 
Understanding the precarity of migrants' position in Morocco means situating their experiences within their social and legal frameworks. In 2003, the Moroccan state passed a new law (law 02-03) on the entry and stay of aliens in Morocco and illegal immigration and emigration. This law criminalises irregular immigration and emigration, as well as its assistance and allows the Moroccan border police to refuse entry to foreigners - although those who do not need a visa to enter Morocco - who are suspected of having insufficient financial means or of being a threat to public order (Perrin 2009, p. 262). This new legal framework was accompanied by a migration policy directed against sub-Saharan migrants, with the reinforcement of border controls and widespread raids against sub-Saharan communities across the north of the country and in specific suburbs of Morocco's main cities (Collyer 2007, p. 673). Enacting and implementing this new law and policies was not a response to citizens' demands but rather resulted from pressure emanating from the European Union and from the Euro-Mediterranean accords signed by Morocco (Perrin 2009, p. 248). Furthermore, this shift in migration policy was part of a broader national agenda to improve Morocco's political weight and enable it to become a 'pivotal partner' for Europe in the region (Natter 2014, p. 17). In the latter half of 2013, connections between Morocco's migration and foreign policies became more visible when the Moroccan state initiated a procedure of regularisation of 18,000 undocumented migrants seeking residency status in Morocco. This represented two-thirds of the total 27,332 who had asked for residency. This regularisation was launched to demonstrate the country's respect for human rights and its close relationships with other African states (Cherti and Collyer 2015, p. 591). This operation contributed to the more permanent settlement of migrants who acquired a residency status. However, this procedure also resulted in massive police raids in the informal settlements in the northern part of the country during which 1,200 migrants were arrested (Khrouz 2015). In such ways, the security-based migration policy of Morocco has contributed both directly and indirectly in the vagrancy of undocumented migrants.

Indeed, many migrant respondents in Fès told of how their encounters with the Moroccan state pushed them towards itinerancy as they were forced to move back and forth between Morocco and Algeria. Some had been expelled more than four times by Moroccan security forces via the Moroccan-Algerian border. Each time they immediately returned to Morocco (Interview 13, Beninian, male). Others were arrested while climbing fences surrounding Ceuta and Melilla and were expelled by the Moroccan border police at the Algerian border, immediately making their way back on foot towards Morocco (Interview 7, Liberian, male).

Aspirations to move on

While this geopolitical context has reinforced the spatial instability of migrants in Morocco, their mobile way of life is also a result of their aspirations to reach Europe. Even the 
possibility of regularising their stay in Morocco does not deter people from trying to move on. Hence, many migrants who applied for residency during the regularisation procedure were no longer in Morocco when their application was approved (Bentaleb 2015). This desire to move on was also evident in the interviews conducted in 2010. As a 39-year-old migrant from the Central African Republic put it, 'We don't come here in order to stay. It is just a stopover to get some rest for three or four months, before going back to the border' (Interview 39, Centrafrique, male). This migrant - who had arrived in Fès two months before - had been on the road for more than a year and had crossed Benin, Niger, and Algeria before arriving in Morocco. Among the migrants interviewed, only two saw Morocco as their primary destination; they were both football players who came to Morocco with the aim of being hired by a Moroccan football club (Interviews 12 and 20). For all the others, Morocco was perceived as a step, a moment in their migration projects that would enable them to reach Europe. However, because of their inability to continue their journey, many had rethought their migration project. Several were aiming to return to their home country in order to regain strength and save money before taking to the road again (Interviews 2, 3, 12, 41). Others planned to stay in Morocco and save money in order to be able to pursue their goal at a later date (Interviews 18, 28).

At the same time, the feeling of being blocked in Morocco and unable to head northwards drives many migrants to compensate for their forced immobility by circulating among different Moroccan cities. The unsettled state of sub-Saharan migrants is thus not only observable in Fès, but in other cities with stronger labour markets. Indeed, among the interviewees, four had lived and sometimes worked in another Moroccan city before coming to Fès. An Ivorian woman spent a year in Casablanca, and then lived for three in Rabat before deciding to move to Fès (Interview 4, Ivorian, female). A 20-year-old Senegalese settled in Marrakech, then moved to Casablanca where he found a job in a call centre. After few months working there he decided to quit and move to Fès where he expected to meet more Senegalese nationals who had congregated near the shrine of the saint of the Tidjaniyya order to which he was affiliated. Doing so would, he said, give 'spiritual' meaning to his stay in Morocco (Interview 33, Senegalese, male). An Ivorian who found a permanent job in Fès after living in Rabat expressed his desire to move to Casablanca in order to escape the 'boredom' of Fès (Interview 1, Ivorian, male). Indeed, besides the political causes that enforce the constant internal mobility of sub-Saharan migrants living in Morocco, their internal mobility also results from their aspiration to experience different places. It was with the following words that a Beninois explained his move from Oujda to Fès: 'I am an adventurer. I cannot stay in only one single place' (Interview 13, Beninois, male). The concept of 'adventurer' is discussed in the paper's last section. What I wish to point out here is that migrants' spatial instability is influenced by migrants compensating for their inability to travel to Europe with mobility within Morocco. For that reason, most individuals have a temporary outlook on their stay in Fès and many stay only a short time in order to have a rest and move again elsewhere in Moroccan. This, along with their very limited social networks, reinforces the ephemeral nature of their presence in the city. 
In contrast to other Moroccan cities where migrants can stay in 'hostels' run by former migrants, Fès' sub-Saharan migrants usually rely on spontaneous encounters. Respondents told of having to spend days and sometimes weeks walking around and sleeping at the train station before finding a person ready to help them (Interview 3, Cameroonian, male; Interview 20, Burkinabé, male; Interview 33, Senegalese, male). Many migrants arriving in Fès were supported by students encountered on the street. Due to their formal legal status, these foreign African students are important intermediaries that can help migrants in the city. This includes both immediate assistance such as offering migrants a place to stay or student associations founded by foreign Africans providing migrants with basic support (Interview 32, Burkinabé, male). They can also enable migrants' social insertion by including them in social activities and events (Interview 2, Ivorian, male; Interview 28, Guinean, male) or helping them find work (Interview 42, Burkinabé, male). However, students' solidarity had its limits. Where accommodation was offered, the migrants were indirectly asked by their hosts to contribute to the food and rent expenses after a few weeks. This generally prompted migrants to move out and stay with other irregular migrants with whom they claimed to feel a closer bond, or to move on to another Moroccan city (Interview 18, Ivorian, female; Interview 39, Centrafrique, male; Interview 38, Ghanaian, male).

The short duration of migrants' installation in Fès and their vagrancy are also linked to the precarious employment situation in Morocco. Only around a third of the interviewed migrants had succeeded in finding jobs in Fès and most had odd jobs or domestic work in the informal sector (Berriane et al. 2013). The most successful were the educated migrants who had managed to find relatively well-paid occupations in international call centres that have increasingly been outsourced to Moroccan cities, including Fès (Interview 31, Ivorian, male). However, such workplaces are rarely sites for encounters that contribute to durable social relations between Moroccans and migrants.

Although the presence of an individual migrant appears as ephemeral and temporary, during his or her sojourn, each migrant connects with other mobile and settled sub-Saharan residents and therefore contributes to the permanent presence of 'Africans' as a group. Although the individuals forming these communities may change continuously, they are replaced by new ones contributing to the constant existence of sub-Saharans in the city. The ephemeral dimension of the migrants presence as individuals reminds us the role of Simmel's stranger 'as representative of the other group' rather than of its individuality (Helle 2001, p. 164) and draws the question of the social relevance of the interactions between migrants and locals. What are the social connections and exchanges that take place in everyday life between the migrants and their Moroccan hosts and to what extent is the migrant's individuality relevant in these interactions? 
Two sites of encounter have been distinguished by the migrants in their narrations: the city street and the neighbourhood. Whereas the street is largely experienced as hostile, the smaller scale of the neighbourhood enables the production of more positive social relations between migrants and locals. However, even in the neighbourhood, the host-guest relationships go along with social distancing and self-segregation and in most of the cases; the migrants are rather representative of a group than perceived as individuals.

Sub-Saharan presence in urban space: economic opportunities and hostility in the street

The street, that is also the main place for migrants to find a job or any kind of income, represents one of the main spaces of encounter of locals. Sub-Saharan migrants develop creative economic strategies that may not produce large incomes, but do have visible impacts on the places through which they pass. On the one hand, as traders and pedlars they contribute to the circulation of new commodities such as African fabrics, or they meet the demand for African food products and services (for example, hair plaiting) from the subSaharan student community or Moroccans who have adopted African hairstyles and food (Interview 18, Ivorian, female; Interview 28, Guinean, male). On the other hand, their physical presence is visible as they circulate daily offering their labour to people in the street or in the markets (Interview 28, Guinean, male; Interview 12, Togolese, male). Special sites in Fès are well known as recruitment places for daily workers - Moroccans, as well as subSaharans - as cleaners, gardeners, or construction workers (Kettani and Péraldi 2011). At the same time, most respondents said they had resorted to begging at various times during their stay in Morocco (Interview 20, Burkinabé, male; Interview 22, Nigerian, male; Interview 27, Gambian, male). Individual sub-Saharan vagrants searching for jobs or asking for charity have subsequently become part of Morocco's urban landscape, where they are widely identified as victims and supplicants.

Sub-Saharan migrants consider the street as a hostile space where, in addition to their stigmatisation as a vulnerable group, they experience verbal and non-verbal aggression by locals. It is in the street that they are insulted by children, as well as by adults (Interview 18, Ivorian, female). The sub-Saharan migrants see their dark skin as the main reason behind these hostile reactions and their rejection by the local population (Interview 12, Togolese, male). It might be quite possible that the historically rooted association between blackness and the vulnerable social status of slaves has not disappeared from the Moroccan collective memory and has been reactivate or reproduced in the interactions between Moroccans and the legally and socially vulnerable sub-Saharan migrants.

This cycle of negative interactions have shaped migrants' strategies of approaching and seeking help from other sub-Saharans rather than a more hostile Moroccan population. It reflects an 'intimate apartheid' (Bourgois and Schonberg 2005) in the sense of a self- 
segregation that has been incorporated by the migrants. However, while talking about the 'street', migrants mainly referred to streets that were located away from their places of living. Besides their anonymous dimension, these streets are spaces were social interactions and frictions take place and where migrants contribute through their presence and economic activities in shaping the city.

Social encounters and spatial distancing in the neighbourhood

Turning to the 'neighbourhood' - the other main space of encounter between sub-Saharans and Moroccan locals - while there is some evidence of more significant social relations, these interactions are still characterised by social distancing. As in most Moroccan cities, Fès' subSaharan migrants are spatially dispersed among the city's various working class districts. They do not gather in exclusively sub-Saharan districts but rather they share their daily life with their Moroccan neighbours. The neighbourhood therefore represents a space enabling closer and more sustained relations between migrants and Moroccans. These relations are further facilitated by the common concerns about securing their future that Moroccans and migrants often share.

Since the young people in my district do not work, every morning everybody is in the street in front of his door. Therefore we meet every day. And there are many people with whom we can discuss. (Interview 15, Ivorian male)

When Ibrahim, the 28 year old Ivorian migrant quoted above, talked about 'everybody' or 'many people', he referred to Moroccan men of his age who, like many other young Moroccans from working-class districts and their sub-Saharan neighbours, are facing few prospects for formal employment. Indeed, many Moroccans share migrants' aspiration to emigrate and reach Europe. This creates further points of solidarity with the sub-Saharan migrants (Alioua 2011). This shared experiences result in proximity and exchanges between locals and migrants with similar socio-economic profile.

More generally the shared space of the neighbourhood also enables more trust as people come to know each other from repeated every day interactions. For example, migrant respondents reported that they benefitted as much as their Moroccan neighbours from loans at the local grocery stores (Interviews 1, 15, 18, 31). This suggests that in the neighbourhood, a certain level of trust is possible between locals and migrants.

Besides that, migrants regularly benefit from acts of charity extended by their Moroccan neighbours. It is quite usual for Moroccan families to bring their sub-Saharan neighbours a plate of couscous (Interview 12, Togolese male; Interview 43, Ivorian, male) or to share meat from a Muslim feast, such as the sheep sacrificed for Aid al-Adha (Interview 1, Ivorian male; Interview 32, Burkinabé, male). Migrants see this common practice of sharing food with neighbours on religious days as a way of demonstrating a degree of confidence and conviviality towards them. However, far from implying more spatial integration and social 
proximity, it is marked by acts of distancing the migrant as 'other'. The interlinkage between conviviality and distancing/suspicion was particularly visible in the account of a Togolese itinerant shoemaker who settled temporarily in Fès:

We have an old mama (une vieille maman) who is living next to us and she gives us couscous very often: the Moroccan couscous with carrots and chicken on top of it. At the beginning we had some trouble with her because her husband seems to be a little bit racist. Every morning he poured motor oil in front of the house, at a place where we were used to sit, at the edge of the street, in order to prevent us from sitting there. But after a while we understood why he behaved like that. It was because he had three young daughters and he didn't want us to pay too much attention to them (Interview 12, Togolese male).

The districts in which most of the sub-Saharans settle were the product of a rural exodus that has been ongoing since the colonial period. These districts have been described as 'villages in the city' in which rural forms of socialities have been reproduced and in which the neighbourhood represents a crucial space of socialisation (Escallier 2001, p. 10). Contrary to the anonymous streets and roads of the city, neighbourhood streets represent an intermediary space in which more social contacts are possible. In this way, sub-Saharan migrants, although they do not settle permanently and are strangers, benefit from similar acts of conviviality by locals than other neighbours.

However, the street of the neighbourhood represents a threshold to the domestic space that is rarely crossed by migrants. Indeed, conviviality towards migrants mainly takes place outside the domestic space. Although some migrants said that they had Moroccan friends, most had never been invited into their homes or met their families. The migrants who were acquainted with single men (Interview 42, Burkinabe, male) were the only ones invited into homes. The introduction into family homes - that is, the domestic space - is by contrast much less common (Interview 17, Malian, male). One migrant told us, 'In Morocco you are never invited in the home of someone. The acquaintance and friendship stop outside the door' (Interview 15, Ivorian, male).

Sub-Saharan migrants who arrive in Fès are confronted by a suspicious Moroccan society in which interactions with foreigners seem rarely to result in lasting social ties. At the same time, charity towards migrants put them at the margins and reinforced their construction as a social group in need: a vulnerable group to be both assisted and kept at a distance. Besides their 'foreign' and unsettled aspect, other social characteristics that are dominant among migrants have probably remarkably shaped the interactions of locals with migrants and their keeping them at distance. The sub-Saharan migrants who shared their experiences with Moroccan neighbours were mainly unsettled single young men. Their insertion in the private space of local families that is - in contrary to the street that is dominated by male - mainly conceived as a female space, would represent an unacceptable transgression of current social norms and gender barriers (Mernissi 1975, p. xii). 
The intermediary dimension of the neighbourhood - that represents a place that enables on the one hand social interactions and a certain level of trust towards strangers and where on the other hand social distancing takes place - is further influenced by temporality. Indeed, besides the impact of sub-spaces (the street versus the domestic space) on the host-guest relationships in the neighbourhood, special moments as the football play for instance, may contribute to the forging of temporal social relations. It is very common for Moroccan and sub-Saharan young males to meet during the afternoons to play football together. However, as expressed by the migrants, sub-Saharans and Moroccans generally play in separate rather than mixed teams and this distinction was frequently expressed by the migrants who referred to themselves as 'we' or 'we the Blacks' (Interview 32, Burkinabé, male). Whilst enabling contacts between young locals and migrants, the football game enacts and enforces racial differences by Moroccans and sub-Saharans. It reifies the sense of belonging among the migrants, who perceive themselves as a group sharing a similar identity.

In the migrant's accounts, the street plays at different scales, a different role as a space for the encounter with others and the experience of urban life. At the scale of the city, the street functions as public space in which migrants are confronted with hostility and experience their otherness as representative of a vulnerable group. At the level of the neighborhood, the street represents an extension of the residential space and functions as a threshold enabling more intimate sociabilities with locals. These sociabilities are however mainly shaped by the migrant's status as black single man and make their integration in the domestic space of the family house of locals extraordinarily difficult if not even impossible.

\section{Public visibility of sub-Saharan migrants and the claim of their right to travel}

While the daily social interactions between migrants and locals emphasise the migrants' social marginalisation and subordination, sub-Saharan African migrants are also developing political consciousness during their stay in Morocco, and mobilise to achieve their rights to move and settle. Such tactical action is visible in their experiences of everyday life, as well as in more organised political mobilisation and public visibility.

Positive affirmations of otherness and the claim for adventure

As noted above, migrants' mobile and unsettled lives are shaped mainly by their aspiration to move on to Europe. In interviews in Fès, migrants' narratives about their journeys and experiences in Morocco reflected a discourse emphasising the need for self-fulfilment and the claim of the right to travel. They defined their migration as a 'journey', 'travel' or 'step out on the road'; for them it is a way to 'find themselves', 'to progress' and 'to look for a better life', 'to make their dreams become real', 'to discover the world' and 'to escape from boredom'. In describing their journeys, migrants typically proudly emphasised the role of their own aspirations and their ability to face the dangers of the journey. 
The terms used by migrants to talk about their migration remind us the concept of 'adventure' that has become commonplace among sub-Saharan migrants in Morocco (Pian, 2009b: 11). The 'adventurer' has been analysed as a category of migration agents (an idealtype) whose migration project and trajectory are not totally defined in advance and thus punctuated with strong uncertainties and numerous bifurcations. For sub-Saharan adventurers their travel is further a mean to discover the world and to liberate themselves from their social and family obligations (Pian 2009b). The adventure represents a migration form that has become mainly popular since the late 1990s as an effect of the individualisation processes taking place in African societies since that time and driving young sub-Saharans to greater autonomy (Bardem 1993). It signals 'a refusal [by the migrants] of the immobility to which a society dominated by an omnipotent gerontocracy condemns them' (Bredeloup 2013b, p.174). Even though they are never completely free of social ties, sub-Saharan migrants want to become 'actors in stories of their own making' and 'to be free' (Ibid.).

Besides their evolving in countries of origin where adventure has become a popular aspect of migration, the journey and stay in Morocco plays also an important role in the development of tactical practices that are useful in order to pursue the adventure. This was particularly visible in the strategies adopted by a Cameroonian migrant towards the Moroccan police. During his first confrontation with the police, he acted as though he were dying to stir the pity of the officers who then offered him protection, shelter and food. During his second arrest at the Moroccan-Algerian border, when he was detained for two days, this same migrant rebelled and claimed his right to receive some food until he and the other detained migrants got something to eat (Interview 3, Cameroonian, male). It seems as the experience with an empathizing Moroccan police officer during his first arrest has encouraged this Cameroonian migrant to become more confident during his second arrest and to claim for his right.

These moments of outrage in the face of the authorities' direct attempts to control their movements make a marked contrast to their largely subordinate behaviour in the street; they articulate their claim of the right to travel and to choose the places where they want to be. As we have seen it in the two confrontation moment with the police described earlier, the behaviour is tactically adapted to the situation encountered. In this way, sub-Saharan migrants tend to emphasise their agency and their ability to manage their life. These claims made evident in the discourse of individuals and specific acts of subversion have been probably influenced by a new political context in Morocco in which irregular migrants have become politically mobilized and more aware of the rights they can claim for locally.

Public visibility and political mobilisation

In late September and early October 2005, several hundred sub-Saharan migrants attempted to cross the barbed-wire border fences separating the Spanish enclaves of Ceuta and Melilla from Morocco. During these two assaults, several migrants were shot or injured by Moroccan and Spanish border control agents, and all the migrants who were able to cross the 
fences were later expelled from Spain. In response, the Moroccan security forces organised the deportation of around 4,000 migrants suspected of having taken part in the assaults across the southern borders of Morocco (Pian 2009a, pp.65-66). These events, which were broadcast in the national and international media, played a huge role in making the issue of immigrants to Morocco more visible (Pian 2009a) and stimulated the expansion of action by civil society to address their concerns. Sub-Saharans started joining forces to demand the recognition of their refugee status and for better regulation of their resident rights in Morocco (Alioua 2009, p.293). This process led to the establishment of several informal associations founded by African migrants with the aims of both highlighting the plight of sub-Saharan migrants for audiences in Morocco and abroad, and also making claims for the recognition of their rights (Pian 2009a, p.75). These irregular migrants' associations became more visible with the cooperation and support of local and international NGOs, which are recognised by the state and can ensure the participation of irregular migrants in demonstrations and public sit-ins. This collaboration indicates further that the processes of mobilisation by migrants can be conceived of as a way to integrate them politically. Indeed, it was striking to see that well-established Moroccan trade unions, such as the Democratic Organisation of Workers (ODT), have created a section charged with the promotion of migrants' rights, and in the case of the ODT this was coordinated by a Congolese asylum seeker (Feliu Martinez 2009). Although no one of my respondents has been involved in such public manifestations and organised political action, the existence of this new rhetoric has probably influenced their growing confidence and self-representation as adventurer and their claim for the right to the Moroccan city.

\section{Conclusion}

The hostile political environment facing undocumented migrants in Morocco, as well as their drive to pursue journeys northwards, lead to the formation of temporary settlements that are in constant reconfiguration. As such the social ties among them are ephemeral, the presence of migrants as individuals is fleeting. Whereas sub-Saharan migrants have become visible in the Moroccan urban landscape, they are rarely conceived of as individuals with distinct biographies and identities. The vagrancy and the begging in the street, as well as their mobility, contribute to the permanent presence of sub-Saharan Africans being viewed as a collectivity, the changing individuals being representative of an itinerant community of strangers.

The main space of encounter and interaction between migrants and locals is the anonymous street, in which migrants participate through their physical presence and economic activities in shaping the city but also experience stigmatisation and hostility, leading them to rather approach other Black Africans - sub-Saharan students, for instance - who play the role of bridges integrating them temporarily in the city. Whereas their different physical appearance - that is, their black skin - is experienced as the main reason for their rejection in the street, in 
the neighbourhoods of popular districts they experience more conviviality with locals. In the neighbourhood, however, the street is also the main site of encounter. It represents a threshold in which the sharing of similar aspirations contributes in the shaping of socialities between sub-Saharan and Moroccans whereas the single young males (who represent the main group of migrants) rarely enter the domestic family houses of their Moroccan peers. This distance is also the result of the migrants' main aspiration to rather circulate than settle permanently in Morocco, an aspiration that might be further enforced by their stigmatisation by locals and the political repression that they encounter as undocumented migrants.

During the last ten years, sub-Saharan migrants have also acquired a public visibility and became more politicised. Their mobilisation has been interpreted as a way to be incorporated from below. This political activism does not always imply that they want to stay permanently in Morocco, since their public visibilisation is rather oriented towards the global community. However, their public visibility implies their social and political involvement in Morocco, and has contributed to the national awareness of the existing human rights and racism issues. In this way, migrants do not only contribute in shaping the cities through their physical and economic presence and the circumstantial social relations that they foster with other sub-Saharans and Moroccan neighbours. During their Moroccan moment, sub-Saharan migrants participate also in raising debates about the rights to emigrate and to travel that concern Moroccan locals as much as sub-Saharan citizens and contribute in this way in shaping the Moroccan society.

\section{References}

Abel, F. and M. Raul (2013) ‘Les dimensions contextuelles de la tolérance à l'égard des immigrés en France : effets de contact et de compétition', Revue française de sociologie, 2013/54 (1):53-82.

Adey, P. (2010) Mobility (Abingdon: Routledge).

Alioua, M. (2011) L'étape marocaine des transmigrants subsahariens en route vers l'Europe: l'épreuve de la construction des réseaux et de leurs territoires (Phd thesis, University of Toulouse).

Alioua, M. (2009) ‘Le « passage au politique » des transmigrants subsahariens au Maroc' in A. Bensaad (ed.) Le Maghreb à l'épreuve des migrations subsahariennes. Immigration sur émigration (Paris : Karthala), 279-304.

Aouad-Badoual, R. (2004) ‘ «Esclavage » et situation des «noirs » au Maroc dans la première moitié du XXe siècle' in L. Marfaing and S. Wippel (ed.) Les relations transsahariennes à l'époque contemporaine. Un espace en constante mutation (Paris : Karthala), 337-360. 
Bardem, I. (1993) ‘L'émancipation des jeunes: un facteur négligé des migrations interafricaines', Cah. Sci. Hum. 29 (2-3), 375-393.

Bentaleb, H. (2015) ‘Bilan en dents de scie pour l'opération de régularisation des migrants irréguliers', Libération. http://www.libe.ma/Bilan-en-dents-de-scie-pour-l-operation-deregularisation-des-migrants-irreguliers a58231.html

Berriane, Johara. (2016) Ahmad al-Tijânî de Fès. Un sanctuaire soufi aux connexions transnationales (Paris : L'Harmattan).

Berriane. Johara. (2012) 'La formation des élites subsahariennes au Maroc' in A. Antil and M. Mokhefi (ed.) Le Maghreb et son Sud : vers des liens renouvelés? (Paris : CNRS Editions), 155-71.

Berriane, M., M. Aderghal, M. Idrissi-Janati and Johara Berriane (2013) 'Immigration to Fes: The Meaning of the New Dynamics of the Euro-African Migratory System', Journal of Intercultural Studies, Vol. 34, No. 5, 486-502.

Boesen, E. and L. Marfaing (2007) 'Vers un cosmopolitisme par le bas?' in E. Boesen and L. Marfaing (eds.) Les nouveaux urbains dans l'espace Sahara-Sahel. Un cosmopolitisme par le bas (Paris and Berlin : Karthala and ZMO), 7-22.

Bourgois, P. and J. Schonberg (2005) 'Un 'apartheid intime'. Dimensions ethniques de l'habitus chez les toxicomanes sans-abri de San Francisco'. Actes de la recherche en sciences sociales 5 no 160, 32-44.

Bredeloup, Sylvie. (2012) 'Sahara Transit: Times, Spaces, People', Population, Space and Place, $18,457-67$.

Bredeloup, Sylvie. (2013a) 'Circumstantial Solidarities and the Transformation of Migratory Networks', Journal of Intercultural Studies, Vol. 34, No. 5, 517-32.

Bredeloup, Sylvie. (2013b) 'The figure of the adventurer as an African migrant', Journal of African Cultural Studies, 25:2, 170-82.

de Bruijn, Mirjam, E., R. A. van Dijk and D. Foeken (2001) Mobile Africa: changing patterns of movement in Africa and beyond (Leiden: Brill).

de Bruijn, Mirjam, E., H. van Dijk and R. van Dijk (2001) ‘Cultures of travel: Fulbe pastoralists in central Mali and Pentecostalism in Ghana' in M. E. de Bruijn, R. A. van Dijk and D. Foeken (eds.) Mobile Africa: changing patterns of movement in Africa and beyond (Leiden: Brill).

Cherti, Myriam and Michael Collyer (2015) 'Immigration and Pensée d'Etat: Moroccan migration policy changes as transformation of 'geopolitical culture", The Journal of North African Studies, Vol. 20, Number 5, 590-604. 
Collyer, Michael (2007) 'In-Between Places: Trans-Saharan Transit Migrants in Morocco and the Fragmented Journey to Europe', Antipode, Vol. 39, Issue 4, 668-90.

Escallier. R. (2001) ‘De la tribu au quartier, les solidarités dans la tourmente. L'exemple marocain’, Cahiers de la Méditerranée 63.

Escoffier, C. (2008) Transmigrant-e-s africain-e-s au Maghreb: Une question de vie ou de mort (Paris : L'Harmattan).

Feliu Martinez, Laura. (2009) ‘Les migrations en transit au Maroc. Attitudes et comportement de la société civile face au phénomène', L'Année du Maghreb V, 343-62.

Gilbert, L. and M. Dikeç (2008) 'Right to the city: politics of citizenship' in K. Goonewardena et al. (ed.) Space, Difference, Everyday Life. Reading Henri Lefebvre (New York: Routledge), 25063.

Gudykunst. W. B. (1983) 'Toward a Typology of stranger-Host Relationships', International Journal of Intercultural Relations, Vol. 7, 401-13.

Helle, H. (2001) Georg Simmel. Einführung in seine Theorie und Methode (Oldenburg: Wissenschaftsverlag).

Marfaing, L. and S. Wippel (2004) 'Espace transsaharien: espace en movement. Quelques réflexions pour une approche conceptuelle - une introduction' in L. Marfaing and S. Wippel (ed.) Les relations transsahariennes à l'époque contemporaine. Un espace en constante mutation (Paris : Karthala), 7-26.

Kettani, M. and M. Peraldi (2011) 'Les mondes du travail. Segmentations et informalités' in M. Peraldi (ed.) D'une Afrique à l'autre. Migrations subsahariennes au Maroc (Paris : Karthala).

Khrouz, N. (2015) ‘Nouvelles politiques d'immigration: entre régularisation, intégration et lutte contre la migration irrégulière', http://www.cjb.ma/123-edito/nouvelle-politique-dimmigration-entre-regularisation-integration-et-lutte-contre-la-migration-irreguliere2927.html

Levine, D. N. (1979) 'Simmel at a distance: On the history and systematics of the sociology of the stranger' in W. Shack and E. Skinner (eds.) Strangers in African societies (Berkeley: University of California Press).

Mernissi, F. (1975) Beyond the Veil. Male-Female Dynamics in a Modern Muslim Society (New York: Halsted Press).

Natter, Katharina. (2014) 'The Formation of Morocco's Policy Towards Irregular Migration (2000-2007): Political Rationale and Policy Processes', International Migration, Vol. 52(5), 1528. 
Park, R. E. (1928) 'Human Migration and the Marginal Man', American Journal of Sociology, Vol. 33, No. 6 (May), 881-893.

Perrin, D. (2009) 'Immigration et création juridique au Maghreb. La fragmentation des mondes et des droits', in A. Bensaad (ed.) Le Maghreb à l'épreuve des migrations subsahariennes. Immigration sur émigration (Paris : Karthala), 245-266.

Pian, A. (2009a) 'Entre 'visibilisation' et 'invisibilisation', les migrations subsahariennes au Maroc' in A. Bensaad (ed.) Le Maghreb à l'épreuve des migrations subsahariennes. Immigration sur émigration (Paris : Karthala), 63-86.

Pian, A. (2009b) Aux frontières de l'Europe. L'aventure incertaine des Sénégalais au Maroc (Paris : La Dispute).

Schapendonk, Joris. (2012) 'Turbulent Trajectories: African Migrants on Their Way to the European Union', Societies, 2, 27-41.

Simmel, Georg. (2009) Sociology: inquiries into the construction of social forms (Leiden; Boston: Brill). 